\section{Rat infestation associated with environmental deficiencies in an urban slum community with high risk of leptospirosis transmission}

\author{
Infestação por roedores associada a fatores \\ ambientais numa comunidade carente com alto \\ risco de transmissão da leptospirose
}

Infestación por roedores asociada a factores ambientales en una comunidad sin recursos con alto riesgo de transmisión de la leptospirosis

\begin{abstract}
We analyzed environmental factors that provide food, water and harborage to rodents and the risk of household rodent infestation in a slum community with a high risk of leptospirosis transmission. Detailed environmental surveys were performed in 221 households. Multivariate regression models evaluated the association between rodent infestation and socioeconomic status and environmental attributes obtained from Geographical Information System surveys. The general household infestation rate was $45.9 \%$. Rattus norvegicus signs were the most prevalent, present in 74\% of the infested households. The risk for rodent infestation was associated with environmental factors supporting harborage for rats, such as dilapidated fences/walls (OR: 8.95; 95\%CI: 2.42-33.12) and households built on an earthen slope (OR: 4.68; 95\%CI: 2.23 9.81). An increase of 1 meter from the nearest sewer was associated with a $3 \%$ (95\% CI: 1\%-5\%) decrease in the risk of rodent infestation. A lack of sanitation where poor people live provides factors for rat infestation and could the target of educational interventions.
\end{abstract}

Rodentia; Leptospirosis; Poverty Areas
Norlan de Jesus Santos 1

Erica Sousa 2

Mitermayer G. Reis 2

Albert I. Ko 2,3

Federico Costa 2,4

doi: 10.1590/0102-311X00132115

\author{
Correspondence \\ N.J. Santos \\ Escola de Medicina Veterinária, Universidade Federal da Bahia. \\ Rua Barão de Jeremoabo s/ $n$, Campus de Ondina, Salvador, BA \\ 40170-115, Brasil. \\ norlansantos@hotmail.com \\ 1 Escola de Medicina Veterinária, Universidade Federal da \\ Bahia, Salvador, Brasil. \\ 2 Centro de Pesquisas Gonçalo Moniz, Fundação Oswaldo Cruz, \\ Salvador, Brasil. \\ 3 School of Public Health, Yale University, New Haven, U.S.A \\ 4 Instituto de Saúde Coletiva, Universidade Federal da Bahia, \\ Salvador, Brasil.
}




\section{Introduction}

Leptospirosis, a disease caused by pathogenic spirochetes of the genus Leptospira, is acquired through contact with animal reservoirs or with a location contaminated by their urine ${ }^{1}$. In Brazil, approximately 10,000 leptospirosis cases are reported yearly with case fatality rates ranging between $10-15 \% 2$. Urban leptospirosis is an important health problem that has emerged due to recent growth of slums ${ }^{3}$. In these areas, leptospirosis affects communities where overcrowding, poverty, and the lack of basic sanitation services create conditions supporting leptospirosis transmission 4,5,6. Additionally, those areas are at risk of other rodent-borne transmission given that rats are carriers of Seoul Virus, Bartonella and other pathogens. Although several animal species may carry Leptospira, synanthropic rodents, from the genus Rattus, are recognized as the most important reservoirs in urban areas 7,8,9. Prevention of leptospirosis is essential given the challenges of leptospirosis diagnosis and clinical treatment as well as the lack of a human vaccine. Campaigns for rodent control, based on the use of chemical rodenticides, have been a major strategy for preventing urban leptospirosis 10. However, chemical interventions are not effective for long-term control of rodent infestations 11 and have important limitations such as the development of rodenticide resistance and potential adverse impacts on non-target species 12. A few major cities in Brazil (São Paulo, Salvador, Recife and Curitiba) have shifted the focus of their interventions from rodenticide-focused pest control to a more holistic approach of integrated interventions (e.g., education, poisoning and environmental modifications). Nevertheless, the lack of knowledge regarding the social and ecological determinants influencing rodent infestation in these settings has been a barrier to implement more effective rodent control 13,14,15,16.

Few studies have examined the environmental determinants of rat infestation in urban habitats in developing countries 17,18. In Brazil, studies to determine factors associated with rodent infestation have been restricted to São Paulo 19 in areas of low leptospirosis incidence. Characterizing the determinants of reservoir infestation is critical to improve leptospirosis prevention. In this work we analyzed the environmental factors that provide food, water, and harborage and the risk of household rodent infestation in a community with high risk of leptospirosis transmission.

\section{Methods}

\section{Study site and study design}

The study area, Pau da Lima (Figure 1), is situated in the outskirts of Salvador, a city of 2,892,625 inhabitants 20 located in Northeast Brazil. Pau da Lima is a densely-populated community of $0.46 \mathrm{~km}^{2}$ divided into four valleys. The area has a high incidence of Leptospira transmission. Incidence of asymptomatic Leptospira infection was 3,780 per 100,000 inhabitants, as determined in cohort studies. Moreover, active hospital-based surveillance identified an incidence rate of 35.4 severe cases of leptospirosis per 100,000 inhabitants 4,5. Between 2003 and 2007 a nested case control study was performed to identify environmental variables in households with and without evidence of Leptospira transmission ${ }^{4}$. We subsequently used a convenience sample of previously collected environmental survey data 4 to assess environmental variables associated with rodent infestation.

Ethical clearance for this study was granted by the Ethics Research Committee of the Oswaldo Cruz Foundation and the Institutional Review Board of Weill Cornell Medical College at Cornell University.

\section{Data collection}

A household environmental survey was performed during October and November of 2007, as described previously 4 . Briefly, we adapted and used a form from the US Centers for Disease Control and Prevention (CDC) manual 13. The form included the following six groups of variables: (a) seven variables on premise type; (b) five variables on food sources for rodents; (c) three variables on water sources for rodents; (d) eleven variables on harborage for rodents; (e) five variables on entry/access 


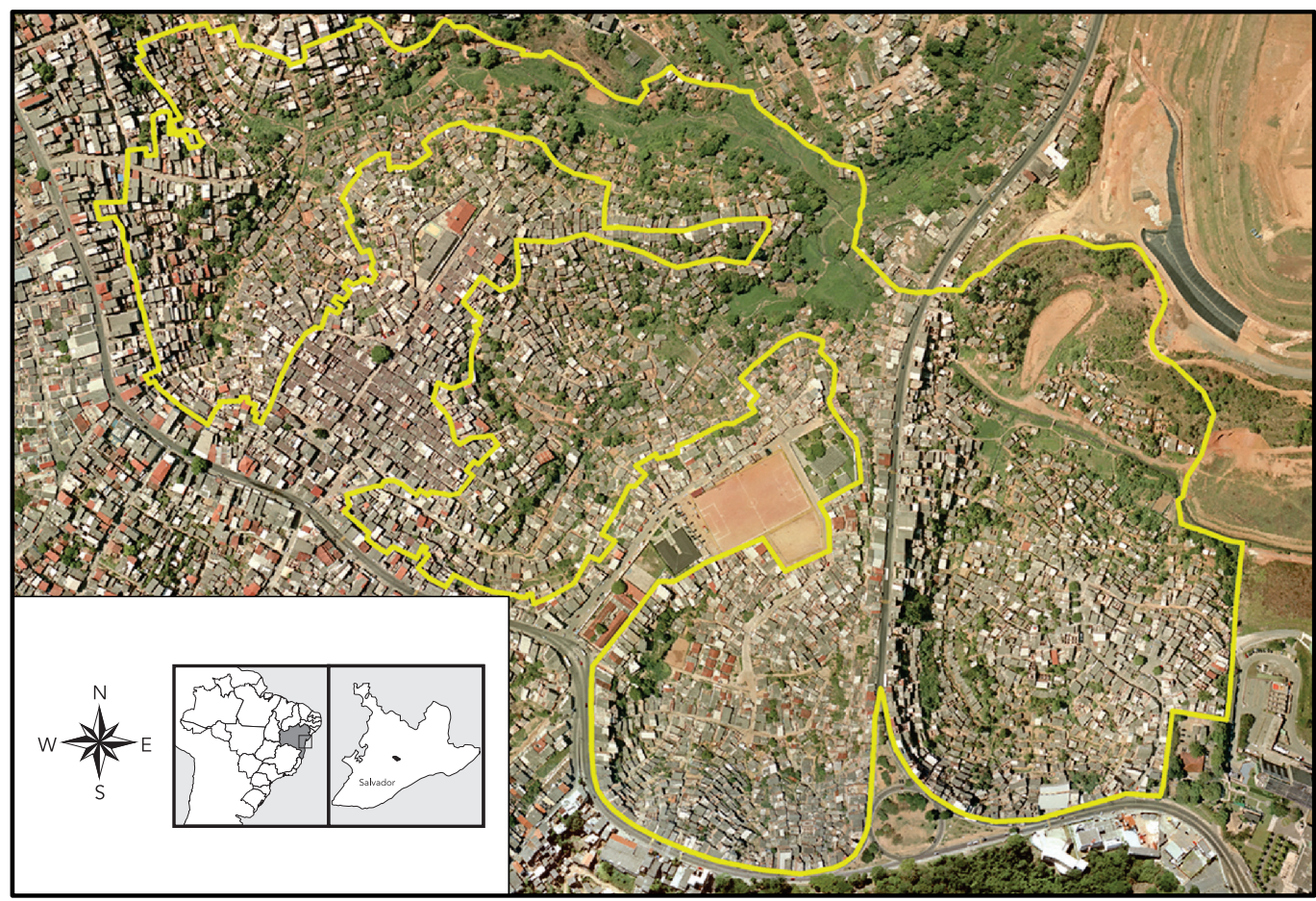

Note: the yellow line in the aerial photograph is the boundary of the study site in the Pau da Lima community.

for rodents; and (f) six variables on signs of rodent infestation. The presence of active signs of rodents qualified as evidence of rodent infestation.

We combined households with and without evidence of Leptospira transmission to evaluate the rodent infestation rate (RIR). Infestation was estimated as follows:

$$
\mathrm{GIR}=[(\mathrm{P} 1 * \mathrm{~N} 1)+(\mathrm{P} 2 * \mathrm{~N} 2)] / \mathrm{T}
$$

where: GIR (general infestation rate), P1 (proportion of infested households with Leptospira transmission), N1 (number of households in Pau da Lima with Leptospira transmission), P2 (proportion of infested households without Leptospira transmission), N2 (number of control households in Pau da Lima without Leptospira transmission) and T (total number of households in Pau da Lima).

Geographic Information Systems (GIS) were used to measure the distance to environmental variables (Figure 2), such as the location and size of open refuse deposits, open sewage, and rainwater drainage systems 6 .

\section{Statistical analysis}

Data for individual subjects were linked by location of residence to spatially-coded information of households and environmental attributes within the study site. Chi-square and t-test were used to compare categorical and continuous data, respectively, in the bivariate analysis.

Generalized additive models (GAM) 21 were used to evaluate the association between significant continuous variables and the rodent infestation. Variables with $\mathrm{p}<0.1$ in the bivariate analysis were 
Figure 2

Topographic map generated by the digital terrain model.

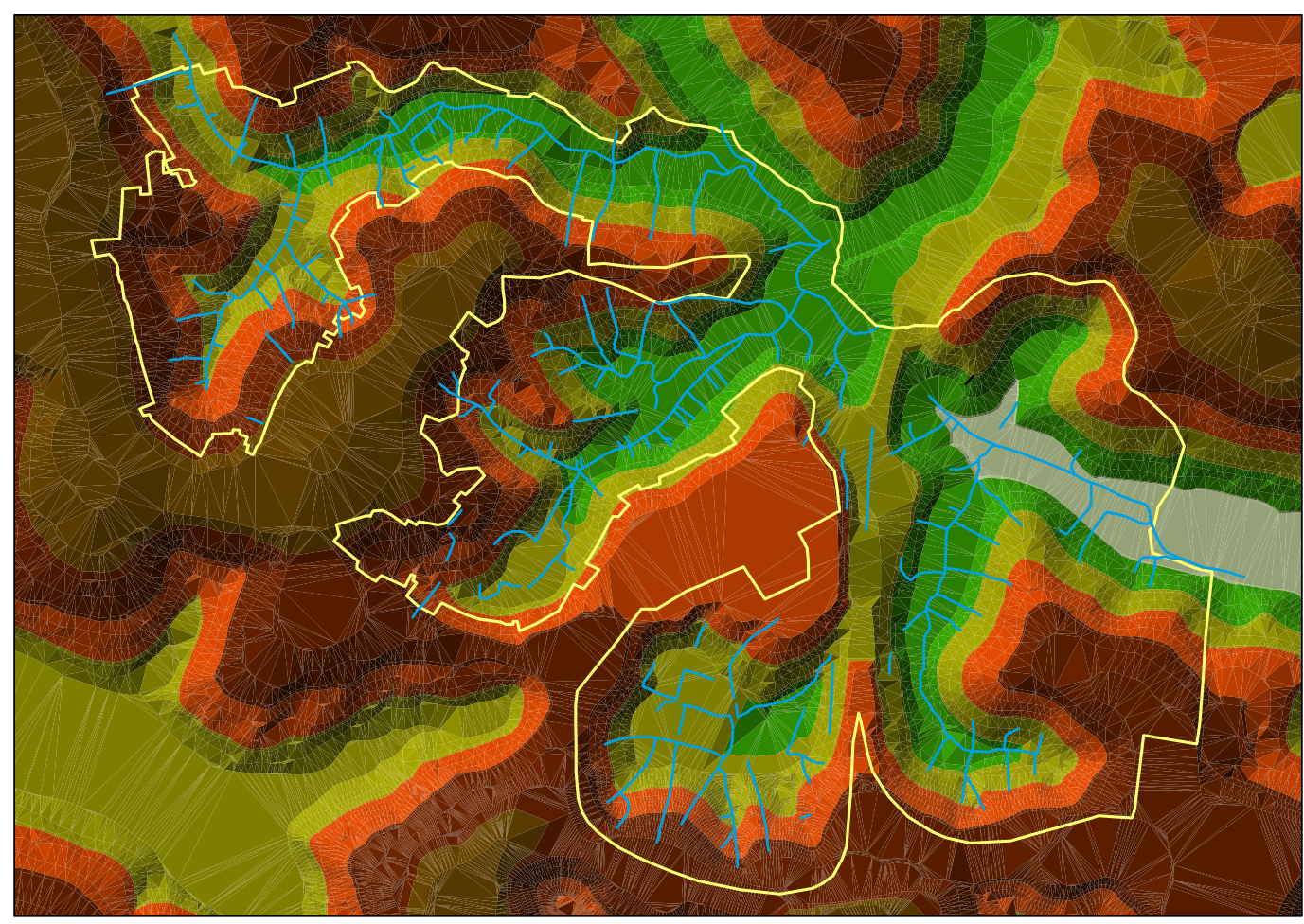

$\begin{array}{llllll}0 & 30 & 60 & 120 & 180 & 240 \quad 300\end{array}$ Meters
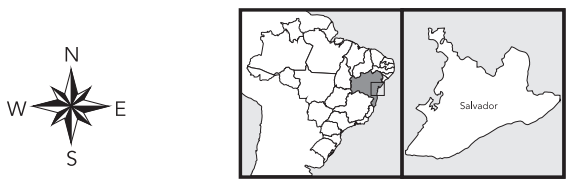

Note: the yellow line is the boundary of the study site in the Pau da Lima community. The blue line shows the distribution of open sewage.

then included in a multivariate, logistic regression analysis. Seven models were used to fit the different blocks of variables based on different types of determinants of rodent infestation. The first model included socioeconomic variables. Models two through six included environmental variables that we hypothesized were related to rodent infestation. The seventh and final model included retained variables from the previous six multivariate models. A backward elimination strategy was performed to obtain models using SAS for Windows software (SAS Inst., Cary, USA). A p-value of 0.05 or less was used as criteria for a statistically significant difference. 


\section{Results}

We evaluated 221 households in the study area, from a total of 684; of these, there was evidence of Leptospira infection in 80; and no evidence of infection in 141. Based on the environmental survey, 137 of the 221 households (62\%) presented at least one sign of rodent active. In the households with evidence of Leptospira infection, 63 (78\%) had signs of rodent infestation. In addition, 74 (52\%) of the households with no evidence of Leptospira transmission were infested. Considering the total number of households with evidence of Leptospira infection $(\mathrm{n}=80)$ and control households $(\mathrm{n}=604)$, the general infestation rate for the study area was calculated at 55\%. More prevalent active rodent signs identified between evaluated households were rodent burrows (79\%), rodent runs (76\%) and $R$. norvegicus feces (74\%). Feces of Mus musculus and Rattus rattus were less frequent (Table 1). The overall rodent infestation distribution can be seen in Figure 3.

In bivariate analyses, we found that the number of household inhabitants and per capita income were associated with the occurrence of rat infestation in the household (Table 2). From the environmental variables 24 were associated with rodent infestation: five such variables related to house characteristics, seven related to water or food for rodents, eight related to harborage, and four to access to the house. Additionally, the risk of rodent infestation was not associated with dogs or cats in the household (Table 2). GAM analysis showed that the risk of rodent infestation had an inverse linear association with the distance of the household to an open sewer (Figure 4). Additionally risk of rodent infestation had an inverse association with increasing elevation of the household from the lowest point in the valley (Figure 5). Increased risk was observed among households located less than a threshold distance of 25 meters from an open sewer or the lowest point of the valley. Of note, the distance of the household to an open sewer was highly correlated with household elevation (Pearson's correlation coefficient $=0.61 ; \mathrm{p}<0.001)$ since open sewers drain into the bottoms of valleys.

To identify independent predictor variables for rodent infestation, we performed multivariate analysis (Table 3). In the seventh and final model, we retained the following five variables: one variable from the premise details group, three variables from the harborage of rodents group and one from the access to rodents group. The risk for rodent infestation was associated with harborage, water, food for rodents, and a quality house indicator. Inappropriate organic refuse storage was associated with approximately a four-time greater risk (OR: 3.98; 95\%CI: 2.12-7.46). Dilapidated fences, household built on exposed earth slope, rubbish, and bush or shrubbery were significant rodent harborageassociated risk factors. Households located less than 25 meters from an open sewer and at the lowest point in the valley had a 2.8 times (95\%CI: 1.3-6.0) increased risk of rodent infestation compared with those located 25 meters or more from these attributes. Un-plastered exterior wall surface and holes in the roof were significant risk factors to rodent access to the household.

Table 1

Active rodent signs identified in 137 infested households.

\begin{tabular}{lcc}
\hline \multirow{2}{*}{ Active rodent signs } & \multicolumn{2}{c}{ Infested households } \\
& $\mathbf{n}$ & $\%$ \\
\hline Rodent burrows & 109 & 79 \\
Rodent runs & 104 & 76 \\
Rattus norvegicus feces & 101 & 74 \\
Mus musculus feces & 20 & 15 \\
Rattus rattus feces & 5 & 4 \\
Rodent hair & 2 & 2 \\
\hline
\end{tabular}



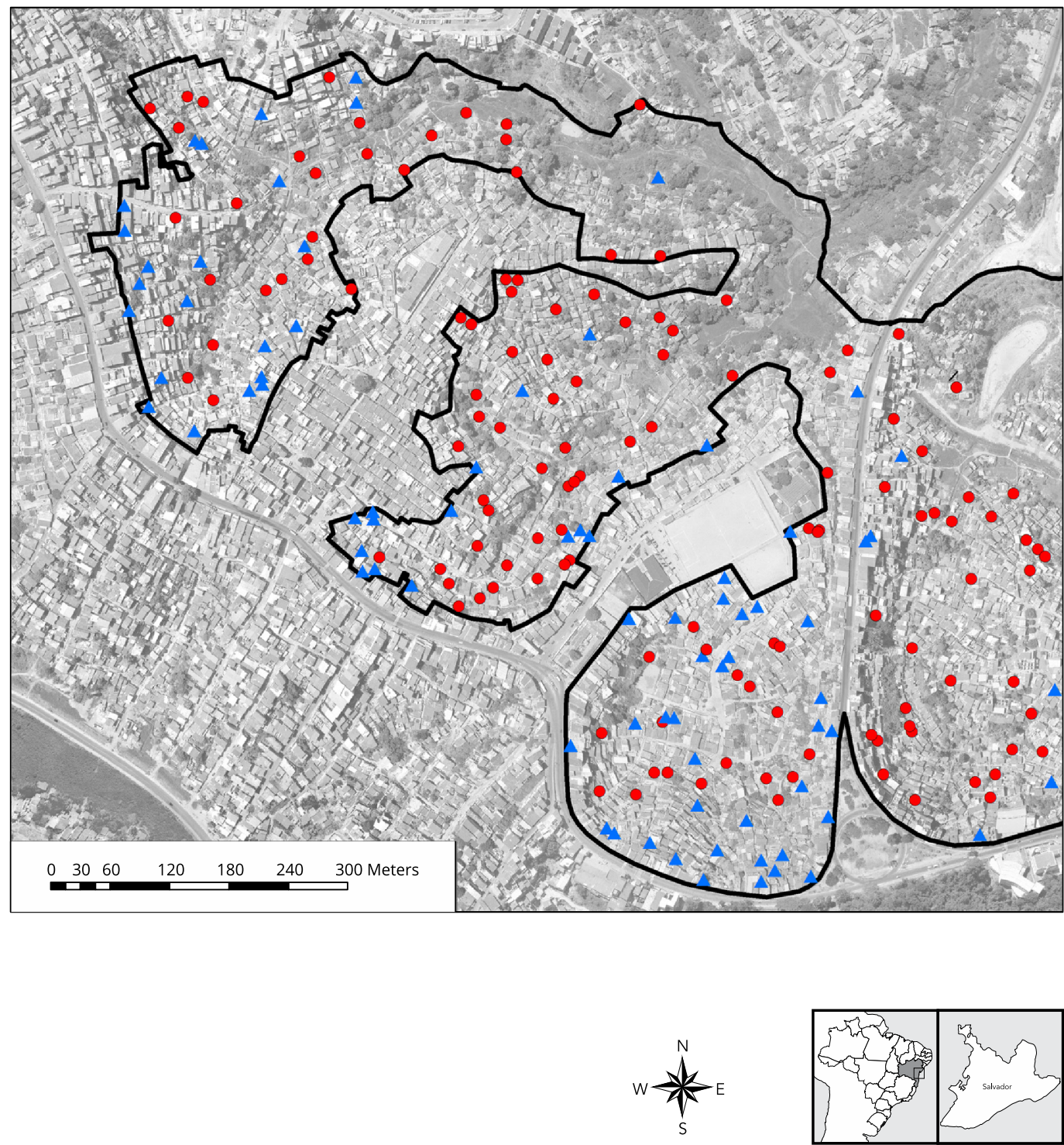

Note: the black line is the boundary of the study site in the Pau da Lima community. The map shown the distribution of rodent infested households (red dots) and not infested households (blue triangles).

\section{Discussion}

The results of our household surveys indicate that rats were widespread in the study area of Pau da Lima during the sampling period in 2007. A high degree of infestation, reaching almost $50 \%$ of households, is not surprising in light of the absence of any significant rodent control measures in Pau da Lima during the survey period. It also reflects the general trend seen in urban areas around the world 19,22, where the poorer the conditions, the higher the level of infestation 23. Areas with infestation rates above $25 \%$ are at high risk of rodent borne diseases 13 . In line with previous work which 
Table 2

Environmental characteristics associated with rat infestation at the community study site. Salvador, Bahia State, Brazil.

\begin{tabular}{|c|c|c|c|}
\hline Variables * & $\begin{array}{c}\text { Infested (n= 137) } \\
n(\%) \text { or median (IQR) ** }\end{array}$ & $\begin{array}{c}\text { Not infested }(\mathrm{n}=84) \\
\mathrm{n}(\%) \text { or median (IQR) ** }\end{array}$ & p-value $* * *$ \\
\hline \multicolumn{4}{|l|}{ Demographics } \\
\hline Number of inhabitants & $4(3-6)$ & $4(3-5)$ & 0.01 \\
\hline Per capita income (USD/day) & $2.5(1.5-4.0)$ & $3.7(2.5-5.5)$ & 0.001 \\
\hline Squatter household & $120(88)$ & $76(92)$ & - \\
\hline \multicolumn{4}{|l|}{ Premise type and details } \\
\hline Residential use only & $136(99)$ & $84(100)$ & - \\
\hline Borders on a vacant lot & $23(17)$ & $5(6)$ & 0.018 \\
\hline Open sewer $<10 \mathrm{~m}$ distance & $48(35)$ & $9(11)$ & 0.000 \\
\hline Distance from open sewer (meters) & $18.4(7.1-30.6)$ & $34.6(19.7-58.3)$ & 0.000 \\
\hline Distance from open refuse deposit (meters) & $69.7(39.7-68.8)$ & $71.3(51.7-98.0)$ & - \\
\hline Level above lowest point in valley (meters) & $18.0(9.4-27.3)$ & $29.6(17.7-41.6)$ & 0.000 \\
\hline Borders on an abandoned house & $28(20)$ & $5(6)$ & 0.003 \\
\hline \multicolumn{4}{|l|}{ Access to food sources } \\
\hline Exposed garbage & $89(65)$ & $22(26)$ & 0.000 \\
\hline Animal food & $53(39)$ & $12(14)$ & 0.000 \\
\hline Other food \& plants & $116(85)$ & $37(44)$ & 0.000 \\
\hline Fruit trees & $81(59)$ & $16(19)$ & 0.000 \\
\hline Open stores of human food & $34(25)$ & $4(5)$ & 0.000 \\
\hline Access to water & $49(36)$ & $12(14)$ & 0.000 \\
\hline Standing water & $38(28)$ & $8(9)$ & 0.001 \\
\hline Leaks & $11(8)$ & $4(5)$ & - \\
\hline \multicolumn{4}{|l|}{ Harborage for rodents } \\
\hline Abandoned vehicles & $0(0)$ & $1(0)$ & - \\
\hline Abandoned appliances & $93(68)$ & $30(36)$ & 0.000 \\
\hline Lumber/Clutter on ground & $113(82)$ & $36(43)$ & 0.000 \\
\hline Other large rubbish & $93(68)$ & $44(52)$ & 0.020 \\
\hline Outhouses/Privies & $26(19)$ & $9(11)$ & - \\
\hline Dilapidated fences \& walls & $51(37)$ & $3(4)$ & 0.000 \\
\hline Plant-related & $119(87)$ & $55(66)$ & 0.000 \\
\hline Bushes or shrubbery & $72(53)$ & $12(14)$ & 0.000 \\
\hline Ornamental plants & $98(71)$ & $51(61)$ & 0.090 \\
\hline Presence of exposed earth & $114(83)$ & $31(37)$ & 0.000 \\
\hline Built on earthen slope & $99(72)$ & $20(24)$ & 0.000 \\
\hline \multicolumn{4}{|l|}{ Entry/Access } \\
\hline Structural deficiencies & $96(71)$ & $29(35)$ & 0.000 \\
\hline Hole(s) in roof & $93(68)$ & $25(30)$ & 0.000 \\
\hline Hole(s) in wall & $27(20)$ & $9(11)$ & 0.070 \\
\hline Hole(s) in floor & $27(20)$ & $3(4)$ & 0.000 \\
\hline Un-plastered walls & $111(81)$ & $45(54)$ & 0.000 \\
\hline \multicolumn{4}{|l|}{ Domestic animals } \\
\hline Dogs & $58(42)$ & $30(36)$ & - \\
\hline Cats & $23(17)$ & $8(9)$ & - \\
\hline Chickens & $17(12)$ & $2(2)$ & 0.009 \\
\hline
\end{tabular}

* Variable definitions available in a previous study 4;

** Numbers and percentages are shown for categorical variables. Median and interquartile range (IQR) are shown for continuous variables of per capita household income, number of persons in the household and presence of an open sewer.

*** p-value by chi square test was estimated for categorical variables. T-test was used for continuous data (continuous data can be identified by the presence of IQR). 
Generalized additive models (GAM) of the association between the risk of rodent infestation and continuous variables of level of household in meters and the distance in meters to the nearest open sewer.

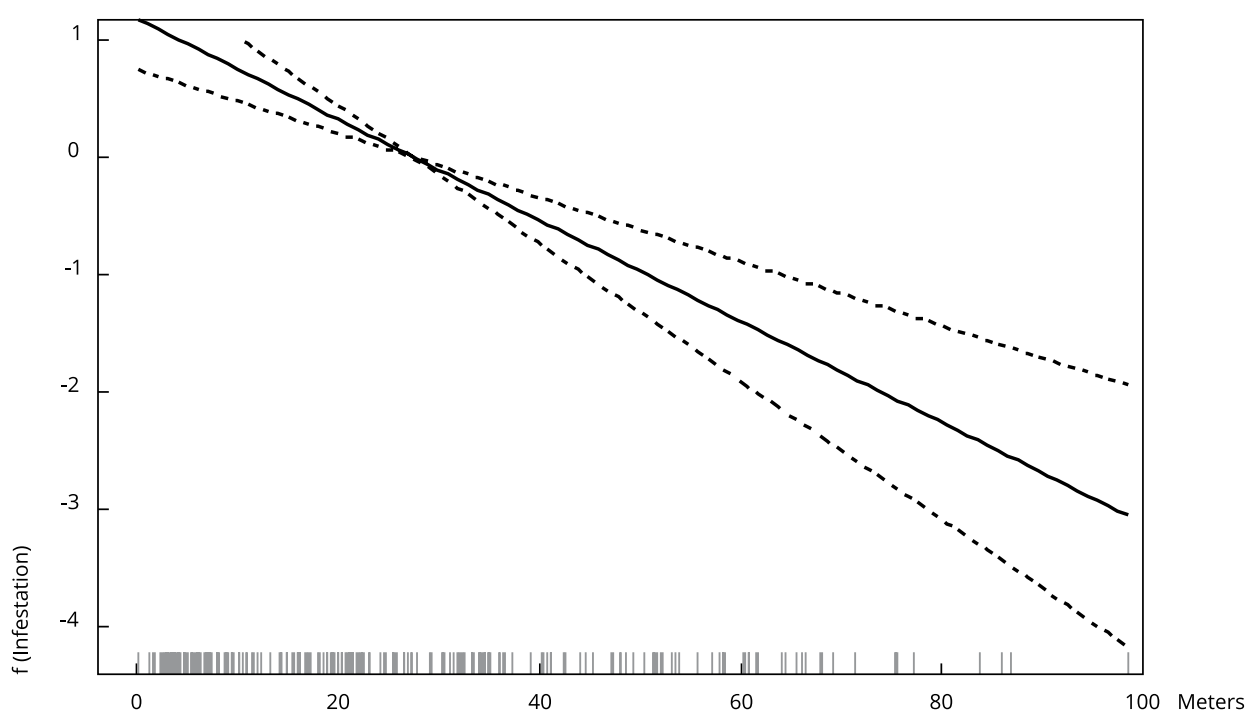

Note: the coefficient $F$ (infestation) in the GAM model is a measure for the risk of rodent infestation. In the panels the $x$ axis intercept values, where $\mathrm{F}$ (infestation) equals zero and were the distance of household to the nearest open sewer.

identified $R$. norvegicus as the dominant species in the urban ecosystem of Salvador 4 , brown rat feces represented $80 \%$ of the rodent feces in our study. This pattern is also observed in other urban areas around the world $22,24,25,26,27,28,29,30$.

The presence of open sewers, which was retained in the model, was an independent risk factor for rodent infestation, likely as the source of harborage. It has been shown that $R$. norvegicus prefers environments with available water, and their presence has been associated with sewers 11,19,31. In addition, GAM analysis found that households had a higher risk of rat infestation when situated within 25 meters from an open sewer (Figure 4) or at the lowest point in the valley (Figure 5). The finding that households had increased infestation risk when located within 25 meters from the lowest point in the valley or sewer suggests that this distance is a proxy for the degree of rat colonization from potential source habitats (sewer) in peri-domiciliary environments.

We observed that food, harborage, and entry points were highly accessible to rodents in the neighborhoods studied. In these complex and saturated habitats, we identified five independent risk factors for rodent infestation. Four of them belong to the harborage category, indicating that suitable places for hiding and nesting are key risk factors to rat infestation in urban ecosystems. In the present study the location of the households on an earthen slope was identified as an independent risk factor for infestation. Similar results were found in previous studies $24,29,31$. Households built on an incline provide suitable space for rodent harborage, and the preference of $R$. norvegicus to select slopes to build burrows was registered in a previous study 32 . The presence of dilapidated fences and walls are described as risk factors for rats in rodent control manuals of both the Brazilian Ministry of Health 10 and the CDC 13. The presence of a dilapidated fence was a risk factor for $R$. rattus but not for $R$. norvegicus in São Paulo 19. Houses with lumber/clutter on the ground had almost nine times the risk of infestation compared to households without this feature. Fences and walls in disrepair provide rodent harborage, which is also associated with rodent infestation in Brazil 19. 
Generalized additive models (GAM) of the association between the risk of rodent infestation and continuous variables of level of household in meters above the lowest point in valley.

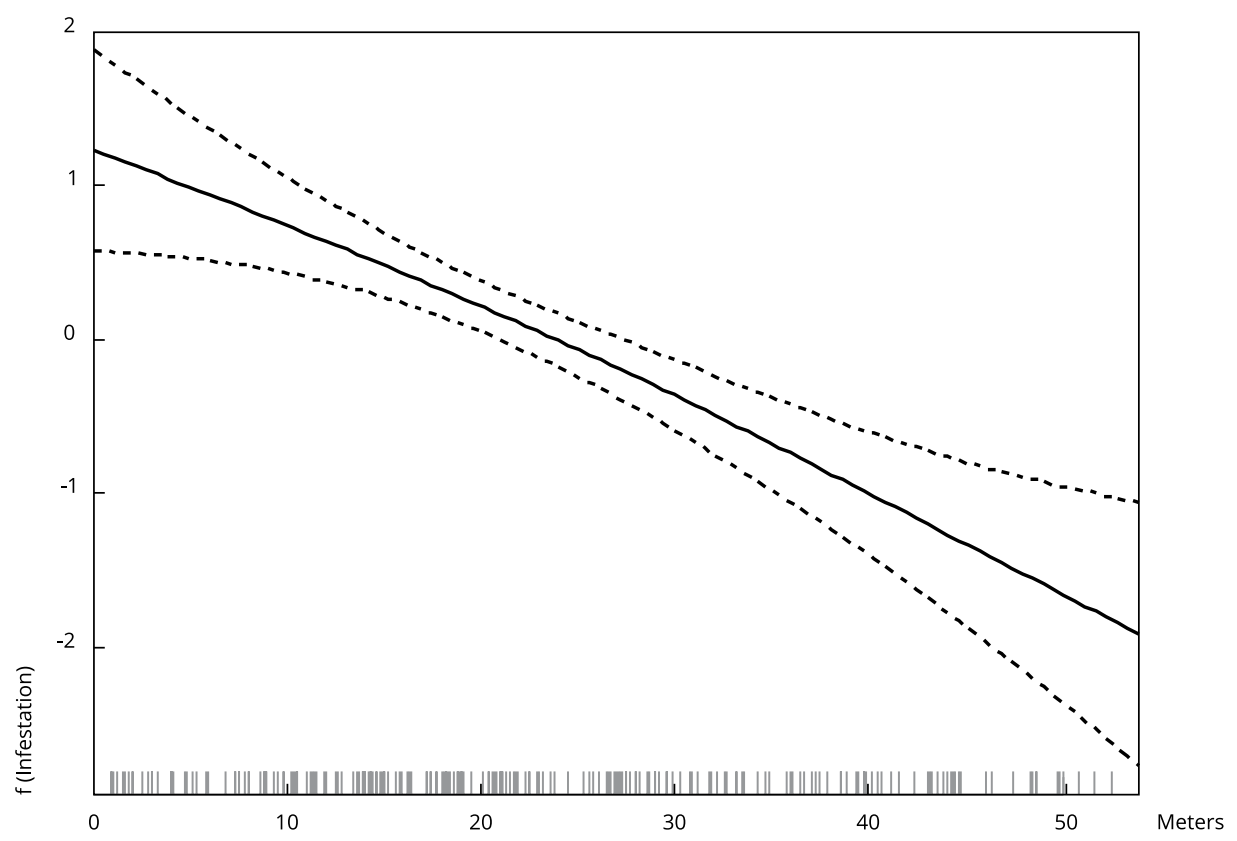

Note: the coefficient $F$ (infestation) in the GAM model is a measure for the risk of rodent infestation. In the panels the $x$ axis intercept values, where $F$ (infestation) equals zero and were the distance of household above the lowest point in the valley is 25 meters.

We observed a large availability of access points for rodents in the neighborhood studied. The only independent risk factor belonging to this group was holes in the roof, a variable initially proposed for rodent access. We believe that holes in the roof may be a proxy for socioeconomic status not captured by the income variable, because $R$. norvegicus, the rodent most frequently found, is not considered a good climber 33 .

The main limitation of the study was the selection for convenience which makes it difficult to generalize our results. In addition the study area has a complex structure with the existence of vegetation, garbage and objects that may obstruct the view of signs of infestation and thus result in an underestimation of infestation rates. Finally, the environmental assessment was carried out in a single season (dry) and so we would encourage further investigation in another season (rainy) due to possible seasonal changes in populations of $R$. norvegicus as observed in temperate countries 4 .

\section{Conclusion}

In conclusion, our findings showed that a high proportion (>44\%) of urban slum households are infested with $R$. norvegicus. The presence of a predominant rodent reservoir in a slum habitat with high risk of leptospirosis transmission highlights the importance of performing an integrated pest management (IPM) program based on $R$. norvegicus ecologies. Intervention must focus on basic sanitation and the elimination of rodent harborage sources, the major causes of rodent infestation in this 
Table 3

Risk factors for rat infestation. Salvador, Bahia State, Brazil.

\begin{tabular}{|c|c|c|}
\hline \multirow[t]{2}{*}{ Variables * } & \multicolumn{2}{|c|}{ OR $(95 \% \mathrm{Cl})$} \\
\hline & Unadjusted ** & Adjusted *** \\
\hline \multicolumn{3}{|c|}{ 1st model: Socioeconomic status of household } \\
\hline Number of Inhabitants & $1.18(1.03-1.37)$ & - \\
\hline Per capita income (USD/day) & $0.86(0.78-0.94)$ & $0.86(0.78-0.94)$ \\
\hline \multicolumn{3}{|l|}{ 2nd model: Premise type and details } \\
\hline Borders on a vacant lot & $3.18(1.16-8.74)$ & - \\
\hline Open sewer $<10 \mathrm{~m}$ distance & $4.48(2.06-9.74)$ & - \\
\hline Distance from open sewer (meters) & $0.95(0.94-0.97)$ & $0.95(0.94-0.97)$ \\
\hline Borders on an abandoned house & $4.05(1.50-10-97)$ & $5.25(1.75-15.79)$ \\
\hline \multicolumn{3}{|c|}{ 3rd model: Access to food sources and water } \\
\hline Exposed garbage & $2.22(2.86-9.51)$ & $3.49(1.83-6.65)$ \\
\hline Animal food & $3.78(1.87-7.63)$ & $2.47(1.14-5.34)$ \\
\hline Other food \& plants & $7.01(3.72-13.2)$ & - \\
\hline Fruit trees & $6.14(3.23-11.68)$ & $4.00(2.02-7.94)$ \\
\hline Open stores of human food & $6.60(2.25-19.3)$ & - \\
\hline Access to water & $3.34(1.65-6.75)$ & - \\
\hline Standing water & $3.64(1.60-8.27)$ & - \\
\hline \multicolumn{3}{|l|}{ 4th model: Harborage for rodents } \\
\hline Abandoned appliances & $3.80(2.14-6.74)$ & - \\
\hline Lumber/Clutter on ground & $6.27(3.38-11.63)$ & $2.61(1.25-5.43)$ \\
\hline Other large rubbish & $1.95(1.09-3.35)$ & - \\
\hline Dilapidated fences \& walls & $16.01(4.80-53.33)$ & $10.48(2.93-37.4)$ \\
\hline Plant-related & $3.52(1.78-6.97)$ & - \\
\hline Bushes or shrubbery & $6.64(3.31-13.34)$ & $2.53(1.10-5.81)$ \\
\hline Ornamental plants & $1.62(0.95-2.88)$ & - \\
\hline Presence of exposed earth & $8.47(4.51-15.91)$ & - \\
\hline Built on earthen slope & $8.33(4.45-15.56)$ & $4.77(2.25-10.10)$ \\
\hline \multicolumn{3}{|l|}{ 5th model: Entry/Access } \\
\hline Structural deficiencies & $4.36(2.44-7.78)$ & - \\
\hline Hole(s) in roof & $4.98(2.76-8.99)$ & $4.01(2.17-7.39)$ \\
\hline Hole(s) in wall & $2.04(0.91-4.59)$ & - \\
\hline Hole(s) in floor & $6.62(1.94-22.60)$ & - \\
\hline Un-plastered walls & $3.70(2.02-6.77)$ & $2.57(1.34-4.91)$ \\
\hline \multicolumn{3}{|l|}{ 6th model: Domestic animals } \\
\hline Chickens & $5.80(1.30-25.8)$ & $5.80(1.30-25.8)$ \\
\hline \multicolumn{3}{|c|}{ 7th model: Significant variables from each block/model } \\
\hline Per capita income (USD/day) & $0.86(0.78-0.94)$ & - \\
\hline Distance from open sewer (meters) & $0.95(0.94-0.97)$ & $0.97(0.95-0.99)$ \\
\hline Borders on an abandoned house & $4.05(1.50-10-97)$ & - \\
\hline Exposed garbage & $2.22(2.86-9.51)$ & - \\
\hline Animal food & $3.78(1.87-7.63)$ & - \\
\hline Fruit trees & $6.14(3.23-11.68)$ & - \\
\hline Lumber/Clutter on ground & $6.27(3.38-11.63)$ & $2.52(1.16-5.43)$ \\
\hline Dilapidated fences \& walls & $16.01(4.80-53.33)$ & $8.95(2.42-33.12)$ \\
\hline Bushes or shrubbery & $6.64(3.31-13.34)$ & - \\
\hline Built on earthen slope & $8.33(4.45-15.56)$ & $4.68(2.23-9.81)$ \\
\hline Hole(s) in roof & $4.98(2.76-8.99)$ & $2.29(1.09-4.79)$ \\
\hline Un-plastered walls & $3.70(2.02-6.77)$ & - \\
\hline Chickens & $5.80(1.30-25.8)$ & - \\
\hline
\end{tabular}

95\%Cl: 95\% confidence intervals; OR: odds ratios.

* Variable definitions available in a previous study 4;

** Unadjusted OR are shown for variables which were significant $(p<0.05)$ in the univariate analyses;

$* * \star$ Adjusted OR are shown for variables which were significant $(p<0.05)$ in the backward logistic regression analysis. 
study. The presence of lumber and dilapidated fences is associated with human behavior and could be targets for educational interventions. Also it is important to maintain constant monitoring of populations of $R$. norvegicus by environmental and health professionals. These results can be used in developing rodent management programs to predict individual household probabilities for rat infestation, to direct control measures, and to assist policymakers in allocating limited resources.

\section{Contributors}

N. J. Santos and F. Costa participated in the project, data analysis and interpretation, as well as a significant contribution towards writing the article. They carried out relevant critical revision of the intellectual content of the article and approved the final version for publication. E. Sousa, M. G. Reis, and A. I. Ko contributed in writing up the article and approval of the final version for publication.

\section{Acknowledgments}

The authors wish to thank the Zoonosis Control Center in Salvador, Bahia State, for their assistance in conducting the study; Ananda Nascimento and Ana Claudia da Silva Batista for database management; and Amelia Kasper for advice during the preparation of the manuscript. Thanks to the Brazilian National Research Council (grants 300861/1996, $554788 / 2006)$, the US National Institutes of Health (grants AI052473 and TW00919) and Capes (Coordination for the Improvement of Higher Education Personnel, Brazilian Ministry of Education).

\section{Conflict of interest}

We declare that none of the authors have any potential conflicts of interest.

\section{References}

1. Ko AI, Goarant C, Picardeau M. Leptospira: the dawn of the molecular genetics era for an emerging zoonotic pathogen. Nat Rev Microbiol 2009; 7:736-47.

2. Secretaria de Vigilância Sanitária, Ministério da Saúde. Sistema de Informação de Agravos de Notificação, Brasil. Brasília: Ministério da Saúde; 2007.

3. McBride AJA, Athanazio DA, Reis MG, Ko AI. Leptospirosis. Curr Opin Infect Dis 2005; 18:376-86.

4. Costa F, Ribeiro GS, Felzemburgh RD, Santos N, Reis RB, Santos AC, et al. Influence of household rat infestation on Leptospira transmission in the urban slum environment. PLoS Negl Trop Dis 2014; 8:e3338.

5. Felzemburgh RDM, Ribeiro GS, Costa F, Reis RB, Hagan JE, Melendez AX, et al. Prospective study of leptospirosis transmission in an urban slum community: role of poor environment in repeated exposures to the Leptospira agent. PLoS Negl Trop Dis 2014; 8:e2927.

6. Reis RB, Ribeiro GS, Felzemburgh RDM, Santana FS, Mohr S, Melendez AXTO, et al. Impact of environment and social gradient on Leptospira infection in urban slums. PLoS Negl Trop Dis 2008; 2:e228.

7. Barocchi MA, Ko AI, Ferrer SR, Faria MT, Reis MG, Riley LW. Identification of new repetitive element in Leptospira interrogans serovar copenhageni and its application to PCR-based differentiation of Leptospira serogroups. J Clin Microbiol 2001; 39:191-5.

8. Ko AI, Galvão Reis M, Ribeiro Dourado CM, Johnson WD, Riley LW. Urban epidemic of severe leptospirosis in Brazil. Salvador Leptospirosis Study Group. Lancet 1999; 354:820-5.

9. Pereira MM, Matsuo MG, Bauab AR, Vasconcelos SA, Moraes ZM, Baranton G, et al. A clonal subpopulation of Leptospira interrogans sensu stricto is the major cause of leptospirosis outbreaks in Brazil. J Clin Microbiol 2000; 38:450-2.

10. Fundação Nacional de Saúde. Manual de controle de roedores. Brasília: Fundação Nacional de Saúde; 2002. 
11. Channon D, Channon E, Roberts T, Haines R Hotspots: are some areas of sewer network prone to re-infestation by rats (Rattus norvegicus) year after year? Epidemiol Infect 2006; 134:41-8.

12. Hathaway SC, Blackmore DK. Ecological aspects of the epidemiology of infection with leptospires of the Ballum serogroup in the black rat (Rattus rattus) and the brown rat (Rattus norvegicus) in New Zealand. J Hyg (Lond) 1981; 87:427-36.

13. Centers for Disease Control and Prevention. Integrated pest management: conducting urban rodent surveys. Atlanta: Centers for Disease Control and Prevention; 2006.

14. Kajdacsi B, Costa F, Hyseni C, Porter F, Brown J, Rodrigues $\mathrm{G}$, et al. Urban population genetics of slum-dwelling rats (Rattus norvegicus) in Salvador, Brazil. Mol Ecol 2013; 22:5056-70.

15. Costa F, Porter FH, Rodrigues G, Farias H, de Faria MT, Wunder EA, et al. Infections by Leptospira interrogans, Seoul virus, and Bartonella spp. among Norway rats (Rattus norvegicus) from the urban slum environment in Brazil. Vector Borne Zoonotic Dis 2014; 14:33-40.

16. Porter FH, Costa F, Rodrigues G, Farias H, Cunha M, Glass GE, et al. Morphometric and demographic differences between tropical and temperate Norway rats (Rattus norvegicus). J Mammal 2015; 96:317-23.

17. Olaseha IO, Sridhar MKC, Obiako PC, Oladapp A. Rat infestations in urban and rural areas in $\mathrm{Ni}$ geria: public health implications. J R Soc Promot Health 1994; 114:300-3.

18. Castillo E, Priotto J, Ambrosio AM, Provensal MC, Pini N, Morales MA, et al. Commensal and wild rodents in an urban area of Argentina. Int Biodeterior Biodegradation 2003; 52:135-41.

19. De Masi E, Vilaça P, Razzolini MTP. Environmental conditions and rodent infestation in Campo Limpo district, Sao Paulo municipality, Brazil. Int J Environ Health Res 2009; 19:1-16.

20. Instituto Brasileiro de Geografia e Estatística. Resultados da amostra do censo demográfico. Rio de Janeiro: Instituto Brasileiro de Geografia e Estatística; 2007.

21. Hin LY, Lau TK, Rogers MS, Chang AM. Dichotomization of continuous measurements using generalized additive modelling: application in predicting intrapartum caesarean delivery. Stat Med 1999; 18:1101-10.

22. Fernández MS, Cavia R, Cueto GR, Suárez OV. Implementation and evaluation of an integrated program for rodent control in a shantytown of Buenos Aires City, Argentina. Ecohealth 2007; 4:271-7.
23. Meyer A. Urban commensal rodent control: fact or fiction? In: Singleton GR, Hinds LA, Krebs CJ, Spratt DM, editors. Rats, mice and people: rodent biology and management. Canberra: Australian Centre for International Agricultural Research; 2003. p. 446-50.

24. Traweger D, Slotta-Bachmayr L. Introducing GISmodelling into the management of a brown rat (Rattus norvegicus Berk.) (Mamm. Rodentia Muridae) population in an urban habitat. J Pest Sci (2004) 2004; 78:17-24.

25. Easterbrook JD, Shields T, Klein SL, Glass GE. Norway rat population in Baltimore, Maryland, 2004. Vector Borne Zoonotic Dis 2005; 5:296-9.

26. Childs JE, McLafferty SL, Sadek R, Miller GL, Khan AS, DuPree ER, et al. Epidemiology of rodent bites and prediction of rat infestation in New York City. Am J Epidemiol 1998; 148:78-87.

27. Cavia R, Cueto GR, Suárez OV. Changes in rodent communities according to the landscape structure in an urban ecosystem. Landsc Urban Plan 2009; 90:11-9.

28. Villafaña Martín F, Armas Molina R, Montero Lagos G, Díaz Pérez M. Efectividad en el uso de rodenticid biológico Biorat en comparación con el rodenticida químico para el control de los roedores sinantrópicos en objetivos urbanos de la Provincia de Cienfuegos, Cuba. Bol Malariol Salud Ambient 2000; 11:3-8.

29. Bajomi D, Sasvari K. Results of eight years' examination of the habitats of residual urban Norway rat populations after eradication. In: Proceedings of the Twelfth Vertebrate Pest Conference. http://digitalcommons.unl.edu/cgi/viewcontent. cgi? article $=1007 \&$ context $=\mathrm{vpc} 12$.

30. Cristaldi M, Ieradi LA, De Angelis R. Rodent pest management. Biological and anthropological aspects. In: Zaime A, editor. Fifth International Conference Rodens \& Spatium. Biodiversity and Adaptation. Rabat: Actes Éditions; 1995. p. 185-94.

31. Langton SD, Cowan DP, Meyer AN. The occurrence of commensal rodents in dwellings as revealed by the 1996 English House Condition Survey. J Appl Ecol 2001; 38:699-709.

32. Lore R, Flannelly KJ. Habitat selection and burrow construction by wild Rattus norvegicus in a landfill. J Comp Physiol Psychol 1978; 92:888-96.

33. King CM, Foster S, Miller S. Invasive European rats in Britain and New Zealand: same species, different outcomes. J Zool 2011; 285:172-9. 


\section{Resumo}

O estudo analisou fatores ambientais que facilitam a presença de alimento, água e abrigo para roedores e risco de infestação por roedores numa comunidade com alto risco de transmissão da leptospirose. Foram realizados inquéritos ambientais detalhados em 221 domicílios. Modelos de regressão multivariada avaliaram a associação entre infestação por roedores e nível socioeconômico e atributos ambientais obtidos através de inquéritos com Sistemas de Informação Geográfica. O estudo mostrou uma taxa global de 45,9\% de infestação domiciliar. Sinais de Rattus norvegicus eram os mais prevalentes, presentes em $74 \%$ dos domicílios infestados. O risco de infestação por roedores esteve associado a fatores ambientais que forneciam abrigo aos ratos, tais como cercas e muros dilapidados (OR: 8,95; IC95\%: 2,42-33,12) e domicílios construídos diretamente sobre encostas (OR: 4,68; IC95\%: 2,23-9,81). Cada incremento de um metro de distância a partir do esgoto mais próximo esteve associado a uma diminuição de 3\% (IC95\%: 1\%-5\%) no risco de infestação por roedores. A falta de saneamento básico nos locais de moradia das famílias pobres facilita a infestação por ratos e é alvo prioritário para intervenções educativas.

Roedores; Leptospirose; Áreas de Pobreza

\section{Resumen}

El estudio analizó factores ambientales que facilitan la presencia de alimento, agua y abrigo para roedores y el riesgo de infestación por roedores en una comunidad sin recursos con alto riesgo de transmisión de la leptospirosis. Se realizaron encuestas ambientales detalladas en 221 domicilios. Los modelos de regresión multivariada evaluaron la asociación entre infestación por roedores, nivel socioeconómico y características ambientales, obtenidos a través de encuestas con Sistemas de Información Geográfica. El estudio mostró una tasa global de un 45,9\% de infestación domiciliaria. Los indicios de Rattus norvegicus eran los más prevalentes, presentes en un $74 \%$ de los domicilios infestados. El riesgo de infestación por roedores estuvo asociado a factores ambientales que proporcionaban abrigo a las ratas, tales como cercas y muros derruidos (OR: 8,95; IC95\%: 2,42-33,12) y domicilios construidos directamente sobre pendientes (OR: 4,68; IC95\%: 2,23-9,81). Cada incremento de un metro de distancia, a partir del alcantarillado más próximo, estuvo asociado a una disminución de un 3\% (IC95\%: 1\%-5\%) en el riesgo de infestación por roedores. La falta de saneamiento básico en las viviendas de las familias pobres facilita la infestación por ratas y es el objetivo prioritario para intervenciones educativas.

Roedores; Leptospirosis; Áreas de Pobreza
Submitted on 15/Aug/2015

Final version resubmitted on 18/Mar/2016

Approved on 23/Mar/2016 